\title{
Temporary employment contracts in academia: a real option view
}

\author{
Malcolm Brady \\ Dublin City University \\ Dublin 9 \\ Ireland \\ Tel.: +35317005188 \\ Email: malcolm.brady@dcu.ie
}

\begin{abstract}
This paper examines the strategic use of temporary employment contracts in dealing with supply uncertainty in the form of employee ability that is slow to reveal itself, for example in academia where there exist significant time lags in demonstration of research ability. A temporary contract is modelled as a real option, specifically as a combination of put option and stock, known as a protective put. The option price is modelled as relief from project work, e.g. teaching, and the exercise price is modelled as a target value, e.g. requisite number of publications. The model provides an explanation for contrasting use of temporary contracts in research and in teaching intensive institutions and for teaching only and research only staff. The model has relevance in other employment situations where there is a time-lag between recruitment and revelation of employee ability, for example in young professional, top executive and political positions.
\end{abstract}

Keywords: real option, temporary employment, academia, protective, put, uncertainty 


\section{Temporary employment contracts in academia: a real option view}

Use of temporary contracts is widespread in the third level academic sector (Robin \& Cahuzac, 2003) with tenure levels falling and use of adjuncts increasing (Kaplan, 2010). Use of temporary contracts to employ academics is prevalent across the globe: in Australia (Coates et al., 2009), France (Bonnal \& Giret, 2010), UK (Anderson, 2007; Chakrabortty \& Weale, 2016) and USA (Feldman \& Turnley, 2004; Frederickson, 2015). Temporary contracts keep costs down in light of massification of higher education and tightening university budgets (Bryson, 2004). However, use of temporary contracts to reduce costs and achieve flexibility comes at a price. Extensive casualization is leading to a two-tier system of protected core academic staff and an insecure periphery (Kimber, 2003; Ryan et al., 2013) with consequent intensification of work, self-exploitation and hollowing out of teaching quality (Bryson, 2004; Brown et al., 2010). Growing use of contingent faculty also has adverse effects for students (Ehrenberg \& Zhang, 2005).

Temporary employment contracts are widely used by organizations as a mechanism to reduce uncertainty (Güelle \& Petrongolo, 2007). By their nature they provide flexibility to the organization: to fill temporary gaps in resources or to reduce the impact of uncertainty in demand and supply. Being time limited, temporary employment contracts entail a natural abandonment process: the organization may choose to terminate a person's employment at the end of the contract period. Indeed, one of the functions of the human resource department is to end or renew temporary contracts in a timely and rational manner. The concepts of uncertainty, irreversibility, flexibility and delay are core to real options theory; it may be fruitful therefore to examine more closely temporary employment contracts from the aspect of real options.

The ability to delay a decision that is difficult to reverse, and to wait for new information to arrive, provides an organization with additional flexibility in dealing with environmental 
uncertainty (Pindyck, 1991). Such an ability to delay a decision can be regarded as a real option i.e. 'the right, but not the obligation' to take a specified action at some future point in time (Luehrman, 1998:51). Real options include the right but not the obligation to initiate or expand, to speed up or delay, to contract or abandon a project (Merton, 1998:339). Investment in organizational resources can be viewed as a strategic option (Bowman and Hurry, 1993). Temporary employment contracts are a form of resource investment, providing the organization with the right but not the obligation to abandon an employee at the end of the contract period.

Real options have the advantage of reducing downside risk while maintaining upside potential (McGrath et al, 2004). A temporary contract limits the risk to which the organization exposes itself: an employee whose performance is unsatisfactory can be let go at contract end. Inherent in providing the flexibility associated with real options is an efficient abandonment process (Adner \& Levinthal, 2004a): the organization must be prepared to discontinue an option if it believes that course of action is not working out. In order to abandon a course of action effectively, managers must exercise their option rights in a timely and rational manner (Copeland \& Tufano, 2004). A formal abandonment process entails a trade-off in that the option holder may forego some ability to capitalise on serendipitous opportunities; this represents a cost of taking out an option (Adner \& Levinthal, 2004b).

There is a small but growing literature on use of real options in the field of human resource management. However, only a small number of writers have looked at temporary employment contracts as real options and none to date have attempted to formally model a temporary employment contract as a real option. This paper puts forward a model of a temporary employment contract as a real option, drawing on options theory from the field of finance. The paper is conceptual in nature and examines the logical elements of temporary contracts from an options point of view and demonstrates how options create flexibility and 
reduce irreversibility in an uncertain environment. The paper takes employment of young academics as an example and argues that the third level sector is using temporary contracts in a strategic manner to test out employees before offering them a permanent position: i.e. academic organizations are using temporary contracts as a form of real option.

Framing temporary employment contracts in academia as real options introduces to the field a set of novel concepts and rigorous intellectual tools that may be useful in examining more explicitly, and under a new lens, the detailed and complex mechanism of their implementation. An option lens 'clarifies details of the underlying choice mechanism' (Bowman and Hurry, 1993:765). The elements of real options theory allow the explicit examination of the analogous elements of temporary employment contracts; in particular, the real options framework encourages a more focused examination of the price, benefits, timelags and trade-offs associated with temporary contracts in academia. Recognition of these costs, benefits and trade-offs may assist employers make better employment decisions. Clearer identification of the elements of option based employment contracts may also be useful to employees who are not always aware of the full nature of the option that may be embedded in a temporary contract. Early recognition and understanding of these elements may allow the employee better manage their employment situation and their career. The model has relevance more generally in employment situations where there is a time-lag between recruitment of the employee and the revelation of that employee's ability as is often the case for young professional, senior management and political positions.

\section{TEMPORARY EMPLOYMENT CONTRACTS}

Temporary contracts, also called fixed-term or closed-end contracts, are used for two main purposes: to fill a short term gap and as screening devices to mitigate uncertainty (Güelle \& Petrongolo, 2007). The first purpose is largely operational and is to fill a position for a short period of time or to carry out a well-defined role on a project (Connelly \& Gallagher, 2004). 
Filling a short term gap may be, for example, to replace an employee who is taking maternity leave. There is relatively little uncertainty here: the leave period is well-known and the duties to be carried out during the temporary contract are also well-known. There is also little uncertainty in a project role; projects are usually professionally planned and the duties and duration of resource roles well-specified. Even if something unanticipated happens the role is linked to a project which will ultimately end, and the role with it.

The second purpose is largely strategic and is to deal with uncertainty of some kind, usually uncertainty in demand or in supply. Firms regularly resort to the use of temporary workers as a buffer when dealing with unexpected fluctuations in demand (Lotti \& Viviano, 2012; Mangum et al, 1985; Pinker \& Larson, 2003). Organizations can cope with such exogenous uncertainty by taking on employees for a specified period and then seeing how demand evolves. If demand turns out to be sufficient to continue the project then the temporary employees may be offered further employment; if demand is insufficient then the employees are let go at the end of the temporary contract.

Organizations also use temporary contracts strategically to reduce uncertainty in supply. Use of temporary workers may reduce costs to employers and mitigate labour market rigidities particularly in countries where it is difficult for employers to terminate the employment of permanent staff (Kalleberg, 2000). Temporary contracts are used strategically to assess the competence of an employee before making an irreversible employment decision (van Emmerik \& Sanders, 2004). This occurs when the organization is faced with hiring an employee whose true ability is not well known or not yet fully revealed. Firms reduce this uncertainty by offering the employee a temporary contract during which the employee is given the opportunity to reveal his or her true ability. However, the advantages of lower costs and increased flexibility are traded off against the risk of employees quitting early (Güelle \& Petrongolo, 2007), imperfect transfer of knowledge to the permanent organization (Sydow, 
Lindkvist \& DeFillippi, 2004) and dissipation of knowledge through organizational amnesia (Grabher, 2004). The particular focus of this paper is on supply-side uncertainty due to opaque employee ability.

\section{REAL OPTIONS}

The real option concept originated in finance in the mid 1970's and has since made steady inroads into the management literature (Amram \& Kulatilaka, 1999; Bowman \& Hurry, 1993; Janney \& Dess, 2004; Trigeorgis, 1996; Zardkoohi, 2004). Real options have been used in conjunction with transaction cost theory (Sanchez, 2003), the resource based view of the firm (Bhattacharya \& Wright, 2005) and scenario planning (Miller \& Walker, 2003). They have been used to examine the strategic value of alliances (McCarter et al., 2011), acquisitions (Smit \& Moraitis, 2010), foreign expansions (Petersen et al., 2000), technology investments (Smit \& Trigeorgis, 2007) and customer relationships (Maklan et al., 2005).

Several authors have used real options in the context of human resource management. Foote and Folta (2002) propose that temporary contracts can be viewed as real options. Bhattacharya and Wright (2005) examined human resource practices more generally in the light of real options. Sanyal and Sett (2011) empirically test Bhattacharya and Wright's theory of human resource options using a questionnaire based quantitative analysis. Trigeorgis and Baldi (2012) suggest that a real options approach may be used to manage a portfolio of human resources. Malos and Campion $(1995,2000)$ use a real option framework to explain the 'up or out' tournament style promotional system commonly used in professional services firms whereby associates compete against their peers for promotion (Brivot et al, 2014:807). A number of authors, mainly labour economists, have put forward formal macro-level models of temporary employment contracts as real options (Chou, 2011; Gete \& Porchia, 2011; Lotti \& Viviano, 2012). Berk and Kase (2010) put forward a formal model of a real option in the human resource arena. They use real options theory to determine 
the value of the increased flexibility in human capital created through employee training by comparing the difference in value of a firm that invests more in training with a firm that invests less in training. However there is an absence in the literature of a formal model of a temporary employment contract as a real option. Nor has real options theory been applied to human resources in an academic context. This paper aims to fill these gaps by putting forward a micro-level model of a temporary contract as a real option and examining this in the context of academia.

\section{A REAL OPTION MODEL OF A TEMPORARY EMPLOYMENT CONTRACT}

This paper suggests that temporary contracts may be used strategically by organizations to allow employees reveal their true ability prior to the organization making the irreversible decision to offer a permanent position. The paper suggests that a temporary employment contract can be modelled as a combination of a put option and the purchase of a stock (figure 1). This combination of a stock and a put is known in the finance literature as a protective put and is used when a buyer expects that the asset will be of high value, but puts a limit on losses should the value of the asset turn out to be lower than expected (Kolb, 1997:373). A put option provides the right but not the obligation to sell an asset, known as the underlying asset. The purchase of the asset and the put option are written on the same day - the start day of the temporary employment contract. The put option is exercised on the day that the temporary contract expires: on that day the organization can choose to let the employee go i.e. sell the asset.

The two key elements of figure 1 are the option price (evident on the vertical axis) and the exercise price, also known as the strike price, (evident on the horizontal axis). Brealey and Myers (1996:560-561) provide an explanation of these graphical conventions used in depicting options. The value of the asset is always equal to the asset price and is represented by the line sloping diagonally to the right. The value of the put option increases as the asset 
value decreases below the exercise price as shown by the line sloping diagonally to the left. Above the exercise price (i.e. to the right) the value of the put option is zero. The combination of the put and the asset is shown by the dotted, kinked, line. The kink in the line, i.e. the non-linearity, is the key to providing the option's flexibility. Below the exercise price (i.e. to the left) the value of this combination is close to zero; above the exercise price (i.e. to the right) the value increases as the asset price increases, as shown by the dotted line sloping diagonally to the right. Such a combination limits the organization's exposure at lower asset prices while accepting slightly reduced value at higher asset prices (Elton \& Gruber, 1995:576).

Figures 1, 2 and 3 approximately here

The recruitment situation can be modelled as a real option similar to a protective put, as shown in figure 2. It is explained as follows. The organization wishes to recruit an employee but is not certain about aspects of the employee's ability. For example, in an academic context the organization may be unsure about a new employee's research ability; furthermore it may take several years before this ability is fully revealed. So, the organization offers the employee a contract for a specific number of years and indicates that if he or she performs well then at the end of the temporary contract period the employee will be retained by the organization. How well the employee has to do is the exercise price for the option. The employee may be given some relief from project work in order to allow opportunity for a more opaque ability such as research to be revealed. This relief corresponds to the price to the organization of taking out the option. For example, in an academic context satisfactory performance may be to produce a specific number of publications in acceptable journals (see 
figure 3). The exercise price of the put option would therefore be the required number of publications, shown on the horizontal axis of figure 3 , and its expiration date is the date of the end of the temporary contract. The price of the option corresponds to relief from project work (for example teaching) given to the employee to allow them opportunity to reveal their research potential. This is shown on the vertical axis of figure 3. At contract expiration date the publication record of the employee is reviewed and, if the person is found to have produced the required number of publications, the temporary contract is converted into a permanent contract. If the person has produced less than the required number of publications then the put option (an option to sell i.e. let go the employee) is exercised by allowing the temporary contract to expire naturally.

This paper gives such a combination of temporary contract and purchase of an asset the label: protective put employment contract. Tenure track is broadly analogous to the protective put option with tenure clock corresponding to expiration date and tenure criteria corresponding to exercise price; the decision to exercise the option or not is taken at the tenure review meeting (Trower, 2005). Note however that criteria for achieving tenure are not always consistent or clearly defined and are being steadily ratcheted up often resulting in employee stress and overload (Austin \& Rice, 1998; Rice \& Sorcinelli, 2005).

The protective put employment contract corresponds to three kinds of real option: the option to invest in stages, the option to defer a major investment, and the option to abandon the investment (Trigeorgis, 1996:10-11). It is not unusual in the real world for options to overlap or their values to interact (Trigeorgis, 1996:227). The protective put corresponds to a staged project because the employment contract is broken into two stages: an early, temporary, stage and a later, permanent, stage. It corresponds to the deferral option because the organization can delay making a final, largely irreversible, decision until more information becomes available; revelation of information can form the basis for a real option (Mittendorf, 2004). 
The put is by nature an option to abandon the asset. The possibility of abandonment provides flexibility to the employer (Adner \& Levinthal, 2004a) because at the end of the first stage the organization has two choices, not one: to retain the employee or to let go an employee that it does not wish to hold on to.

Note that the combination of a stock and a put option is equivalent to a call option (Elton \& Gruber, 1995:579). This can be seen clear graphically in figure 2 where the dotted kinked line has the same shape as a call option. This would imply that a temporary employment contract could also be modelled as a call option and this is indeed true: taking out a call option on an employee for some future date is theoretically possible. The call would only be exercised at some future date if the employee had revealed him or herself to be a satisfactory researcher. In real options terminology this is an option to defer investment. An example of this is where an organization owns land but defers building a hotel on it until a national recession ends. However, in the recruitment situation the organization has no means of binding the potential employee to the organization during the period of the call option. In order to earn a living the employee may join another employer and so may be unavailable at the time of exercise of the call. And, given that these are real options and not moderated by an exchange or other legal mechanism, such a call option may be unenforceable by law. Again, while it is theoretically possible that such a call option could be written up as a legal document, it is not customary to do so in recruitment situations. In contrast, in the protective employment contract model the temporary contract binds the employee to the organization for an interval sufficiently long for the employee's true ability to be revealed.

If the employee reveals higher than expected ability, e.g. produces more than the requisite number of publications, then the employer will have received very good value for purchasing the asset (i.e. employing the employee): the organization could be viewed as being 'in the money'. On the other hand the employee has over-delivered and possibly put in more work 
than was necessary during the temporary contract: in this respect the employee could be viewed as being 'out of the money'. However, this is not necessarily the case: the additional revealed ability may have other career benefits for the employee so it may still be in the employee's best interests to over deliver. In financial options the two parties to the option contract must have different expectations about the future in order for the transaction to take place; by way of contrast in human-based real options it is possible for the two parties to hold similar expectations. In the academic employment situation it is in the interests of both the organization and the employee that more than the required number of publications is produced.

It is worthwhile reconsidering the different motives firms have for using temporary contracts. When a temporary contract is used for operational reasons no option is created. The employee is simply contracted to carry out well-defined work, either replacing an employee or taking on a well-specified project role. The employee does their 'project' work and is paid for their work. On the other hand when the temporary contract is used to give an employee time to reveal their true ability then the employee is being employed both to carry out 'project' work and for the employee's potential to carry out future work. To expect an employee to carry out a full load of 'project' work and also expect an employee to reveal their future potential is asking quite a lot of the employee. Many employers therefore reduce the amount of 'project' work expected from the employee. For example, in the US, academics on 'tenure track' are often given a reduced teaching load in order to allow them reveal their potential as researchers. The organization therefore bears a cost in offering such a strategic temporary contract to the employee: it must employ someone else, possibly on a non-strategic temporary contract, to carry out the teaching not undertaken by the 'tenure track' employee. This additional cost is the price to the employer of buying the put option. 
The more strategic the use of temporary employment contracts the more the organization is prepared to trade off 'project' work for revealed future potential. In academic institutions this becomes: the more strategic the use of temporary contracts the more the institution is prepared to reduce teaching expectation in order to reveal research ability. If an employee sells the put option then the employee knows that he or she will have to work diligently in order to produce the publications required at the expiration date of the option. If the employer has paid a good price for the put then the employee will have a reduced teaching load and can use the teaching time saved for research purposes. The employee will use the time, and possibly more, to produce the requisite research output. Any hours over and above the normal contract hours represent a price paid by the employee for the opportunity to pitch for a possible long term contract. Assume that the likelihood of producing publications is in proportion to the time spent on research. The less time spent on teaching then the more time that is available for research. A consequence of this is that the less time that is spent on teaching then the more publications the academic is likely to produce. The corollary also holds: the more time spent on teaching then the fewer publications the academic is likely to produce. This is still the case even if synergies exist between teaching and research and diminishing returns apply.

Figure 4 approximately here

The contract situation for a teaching intensive institution is shown graphically in figure 4 . The exercise price is likely to be much less at such an institution and is represented as say one publication over the course of a three year contract. The asset value is shown as a diagonal line to the right but the intercept with the vertical axis is much closer to the horizontal axis. 
The downside risk here is therefore quite small. This is because the organization (the buyer) will receive positive value at a much lower level of publication than would a research intensive institution. Comparing figure 4 with figure 3 it is clear that the protection offered (the area between the two horizontal lines to the left of the exercise price) is much less and the loss in value (the area between the two diagonal lines to the right of the exercise price) is much greater than is the case for research intensive institutions. One module of teaching relief provides much less protection than it did for the research intensive institution. Intuitively, because the research expectation is much less so too is the value of the protection. Also, given that research is less strategically important in a teaching intensive institution, it may be the case that so too is the importance of the employee revealing their research ability. Hence it is likely that less time will be provided to the employee to reveal their research ability and so contract durations can be shorter. More generally, this argument suggests that protective contracts are less likely to be used in institutions where employee ability is readily revealed or where 'project' work makes up a large proportion of the work of the institution.

Returning to the research intensive institution, as additional teaching relief is offered to the academic the price of the put goes up accordingly. At the limit, the academic does no teaching at all as shown in figure 5. This would be the case for a post-doctoral position where the employee is a full-time researcher. The put option is now quite expensive as the employee's output must reach nearly double the exercise price before the protective option breaks even. This is a large number of publications and the organization may consider this to be unlikely to happen. Also, the protection provided by the put is close to zero as its lower bound is mostly lower than the value of the asset itself. As the protection is costly and largely defunct, this argument suggests that organizations are not likely to use the protective put employment contract when recruiting post-doctoral researchers. Temporary contracts alone are used, without the implied option to convert to a permanent contract. The employment 
therefore ends for certain at the contract end date and the organization receives whatever number of publications that the researcher has produced. The organization accepts the risk of losing a high output employee and avoids the risk of holding onto to a low output employee. More generally, this argument suggests that an organization is more likely to use a standard temporary contract than a protective contract when there is little opportunity to trade-off 'project' time against time used to reveal an opaque ability.

Figures 5 and 6 approximately here

Another situation to consider is the research intensive institution that offers teaching relief but has a greater research expectation of employees on 'tenure track' than it has of other employees. This has the effect of pushing the exercise price, asset, put and protective put lines all to the right in figure 3 . This makes the protective put even more valuable as it now protects an even greater possible loss in value. However, the higher exercise price may be less likely to be achieved by the employee: the organization must take care not to set the bar so high as to be unachievable. Even if achievable the employee may be forced to draw extensively on their own personal time in order to achieve the target number of publications. This logic applies to many professional employment situations: young lawyers, accountants and consultants devote long hours to ensure that their full professional ability is revealed to their employers in the hope of attaining partnership.

A further situation to consider is that where the organization pays no price for the put option i.e. the institution offers a temporary employment contract with the implied option to continue provided a specified number of publications are produced during the contract period 
but with no teaching relief. In this case the price of the put is zero and the put, asset and combination lines overlie each other as shown in figure 6 (for reasons of clarity these lines are shown with a slight overlap). The institution is now fully protected: it cannot achieve a negative outcome for the protective contract. However it is also less likely that the exercise price will be achieved, and it may even be unachievable. Full protection such as this may not be in the institution's best interest. Unlike in the case of financial options, the value of the real option here can be influenced by the institution. If the institution does not provide the time or the incentive for the academic to fully reveal his or her research potential then it risks losing an employee that, if it had full information, it may prefer to keep. The institution must make a trade-off between fully protecting itself by paying as little as it can for its real option and providing sufficient opportunity for the asset to show its true value.

A final situation to consider is that of the employee taken in on a teaching only contract or visiting professorship. In this case the lecturer is asked to carry out a relatively large amount of teaching, up to eight modules, but is not expected to produce any research output. There is no uncertainty here and so no option is in play: the temporary contract is operational rather than strategic in nature.

Note that this model assumes European style options which are exercised on a single day, known as the exercise date. However similar logic could be applied to convert the model to an American style option; in that case the exercise date for the put option could be any date up to the end of the temporary contract. However, there is generally no advantage to employers to bring forward the end of a temporary contract unless the employee has already fully revealed their ability and there is a danger of the employee being poached by another institution. 


\section{DISCUSSION}

This paper has formally modelled a temporary contract as a real option and used this model to examine the widespread use of temporary contracts in academia, and consequent implications of this on teaching and research activity. One of these implications is that a reduction in the more-obvious activity of teaching is in some circumstances traded off against an increase in the more-opaque activity of research. This implication can be cautiously generalised to other organizational situations where an opaque ability can be favoured over more obvious 'project' ability. For example, politicians may be given leeway from constituency activity and allowed space and time to demonstrate ability to govern. Chief executives may be given some slack in dealing with operational matters in order to develop and show leadership ability. The price of the option is the cost of provision of alternative teachers in academic institutions, or deputies, private secretaries, or personal assistants for politicians and senior executives.

The model demonstrates that using a real option provides more flexibility to an employer than does a standard employment contract in that it allows the organization the option of terminating the employee, and this flexibility may be especially useful when an employee's true ability takes time to reveal itself and in contexts where reversing an employment decision (i.e. letting go an employee) is difficult. Investing in human capital is risky and largely irreversible (Jacobs, 2007). In the case of research the time lag between starting and publishing a piece of work is measured in years. Use of the protective put employment contract mitigates risk by ensuring that the organization retains the employee only if the requisite number of publications is produced within the requisite time. In essence the put option allows the organization transfer risk from itself to the employee. However, there is a trade-off to be made by the organization when using the option: the employee may realise that they may not make the cut, or simply fear that they may not make it, and exit early to 
take up another offer of employment. Early exit of a desirable employee represents an opportunity cost to the organization.

The protective put employment contract meets two of Adner and Levinthal's (2004a) three criteria for a real option: the expiry date is clearly known to all parties at the start of the contract (it is the end date of the temporary contract) and the rules for abandonment are clearly known (a requisite number of publications in certain specified journals). How well Adner and Levinthal's third criterion applies - that the abandonment rules be applied in a rigorous manner - will depend on the nature of the organization itself. Different organizations will vary in the rigor with which they apply the abandonment rule, much as professional service organizations vary in their application of the 'up or out' rule (Malos \& Campion, 1995, 2000). However the pattern of previous abandonment decisions made by the organization gives good insight into the rigor with which the organization applies its own rule.

Note that there are a number of differences in nature between this type of real option and financial or property-based options. Generally speaking for a financial option to be viable there must exist varying expectations about the future: the buyer and seller must hold different views. For example for a call option to be viable the buyer must expect the asset, at the time of exercise, to be of higher value than the exercise price and the seller must expect the asset to be of lower value than the exercise price. On the other hand, in the real option under discussion in this paper both parties may hold largely the same view of the future. Both parties expect that the requisite number of publications will be achieved and it is in the interests of both parties that this number actually be achieved. In contrast to financial options the payoffs of real options to buyer and seller may not necessarily be mirror images of each other. Nor are payoffs in real options necessarily a zero sum game: there may be opportunity 
for increased gain through a synergy or cooperation effect (Chevalier-Roignant \& Trigeorgis, 2011).

The second significant difference is that the human real asset is teleological in nature: it can create and follow its own destiny. Neither financial nor property based assets can do this; they are passive recipients of market changes. Human resources, unlike financial assets, are path dependent; their history counts. Two people in the same career position with the same qualifications are not of the same value: even though they have arrived at the same end point they will have learnt different things along the way. This is what makes humans difficult to evaluate, and provides an explanation as to why organizations resort to option contracts to assist in evaluation.

Third, the human asset is active, not passive, and can hugely influence the outcome of the option through their behaviour. In financial options, once the agreement is made, the asset plays no formal role and acts only passively i.e. its price goes up and down according to the vagaries of the marketplace. However, an employee can choose to work harder, or gain access to a network of colleagues, in order to boost the number of publications produced. On the other hand the employee could also choose to appropriate some of the value of the option by accepting a lower teaching load but then not producing an acceptable number of publications, or producing publications in journals of more interest to the employee than to the employer. In this case the put option is exercised and the relationship with the employee ended, although typically the employee has anticipated this action and has already planned to move elsewhere. Such agency or moral hazard issues do not arise in financial options. Clearly careful ex-post management of temporary contracts is crucial to a successful outcome for employers. 
For employees the implied option also poses difficulties. Because the option contract is implicit (Rousseau, 1989) rather than explicit there is a danger that the employee could fulfil the implied contract, i.e. produce the requisite number of publications, and find that the employer reneges on it. For example, if at the time of exercise of the option the employer chooses to employ another academic with a stronger publication record. This poses a particular difficulty for employees as they may not know for certain at what price the option will be exercised. This danger can be mitigated somewhat by the employee by keeping close to their employer throughout the period of the temporary contract, by observing how other academics on temporary contracts are treated by the institution, and by examining the past history of the institution. If the employer is seen to renege or is found to have a reputation for reneging, then the astute employee will put in place an alternative plan for the future in case when the time comes the outcome of the put option is not in his or her favour. Employees can also make exceptional efforts to reveal their true ability to the employer during the course of the temporary contract, for example by working over and above normal hours, by taking on additional responsibilities, by achieving teaching or best paper awards, by engaging widely with colleagues. On the other hand, if employees realise during the contract period that their true ability lies below the exercise price then they may take different actions: they may choose activities that will build up their $\mathrm{CV}$ to be of interest to new employers rather than to their current employer. Also, the employee may realise that the organization is behaving opportunistically: that it is dangling the carrot of permanency but with little intention of ever offering it. Such a realisation may cause the employee to review their activity. For these various reasons, careful ex post management of the temporary contract by the employee is also critical for a successful outcome for the employee. Frequent review of employee performance may assist both the organization and the employee in obtaining value from the option (Kogut \& Kulatilaka, 2004). 
The strategic view of the employment situation is quite different to the legal view. From a legal point of view the two contracts are two separate events. The first contract, the temporary one, has a clear start and end date and does not per se contain any option to continue. The second contract, assumed to be a permanent contract, is a new legal event and largely unrelated to the first contract; it has a start date but the end date is left open. However, from a strategic point of view the two contracts are two stages of the one employment event, with an option to continue or abandon at the end of the first stage. Indeed the protective put option is generally implied or commonly understood by both parties and not as such a written or legal agreement. The employer indicates that the employee may be kept on permanently provided the employee meets a certain quantity and quality of publication output, thereby implicitly introducing the protective put; the employee understands that this is the case, thereby tacitly writing the protective put. (Note however that the employee may not be fully aware at this point in time that they are writing, i.e. selling, an option on themselves). The protective put option is close to but not exactly the same as the temporary employment contract; rather it is an implied addendum to the contract. The protective put is the difference between a temporary contract put in place for operational reasons and one put in place for strategic reasons.

\section{CONCLUSION}

The paper suggests a simple but formal real option model of a temporary employment contract as a combination of the purchase of an asset and the purchase of a put option. This managerial option incorporates a specified exercise date and clear abandonment rule. This option model suggests a theoretical rationale for the strategic trade-off of one employee ability for another. In the specific case of academia the model suggests a formal rationale for a reduction in teaching expectation to allow the revelation of research ability. The protective put offers greater protection to research intensive institutions which are therefore more likely 
than teaching intensive institutions to use temporary contracts strategically. This structural approach complements that of Clark (1997) who observed that the activities of teaching and research compete for the time and attention of faculty with the 'academic ratchet' favouring discretionary activities over teaching (Massy \& Zemsky, 1994).

More generally, the model provides a rationale for the strategic reduction of 'project' expectations by the organization to allow the revelation of opaque employee ability. The protective put is used to mitigate uncertainty in supply, in contrast to the more common use of temporary contracts to mitigate uncertainty in demand. Human based options are different in nature to property based real options in that the asset itself, not only the investor, can influence events into the future.

Employers need to be clear in their own minds whether they are using temporary contracts strategically as protective puts or when they are using them operationally to fill gaps. When using them strategically the organization must carefully signal to its own personnel and to the temporary employee that there is a possibility of long run employment. This will also require 'option' effort by both the organization and the employee; the organization must be prepared to trade off 'project' effort in order to develop 'option' possibilities; the employee must be prepared to accept a transfer of risk from the organization and may need to be prepared to make extra effort to reveal his or her more opaque abilities.

Closed-end contracts are used in a protective manner in contexts other than academia where a relevant ability takes time to reveal itself. Politicians are elected for a fixed length of time with the option of re-election at the end of the period. Democratically constituted governments are instituted for a specific length of time and then must go back to the people. Senior executives are often recruited on fixed length contracts with the possibility of further contracts should performance be deemed satisfactory. Examination of the option price, 
exercise price, option value, risks, abandonment rules and trade-offs in such human based real option situations provides interesting future research opportunities.

There are a number of limitations to this work. The model applies more to early career academics whose research ability has not yet been fully revealed than to those later in their career who have had significant opportunity to reveal their research ability through their publication history. The model assumes that teaching ability is revealed during the normal employment probationary period and so does not require use of a protective contract for revelation. The model also assumes that the value of a publication is the same for a teaching intensive and a research intensive university. However, it may not be true that the effort required to achieve a publication is independent of the institution to which the academic belongs. Endogenous factors such as academic leadership, collegial support, organizational ethos and institutional reputation may make it easier to publish from one institution rather than another.

The model does not consider premium payments to employees as compensation for the increased uncertainty inherent in a temporary contract; the model assumes that academics accept teaching relief rather than extra payment because the time gained for research represents an investment in the academic's own career. Academic service and committee activity were not taken into account when developing the model and may present interesting avenues for future research.

\section{REFERENCES}

Adner, R., \& Levinthal, D. A. (2004a). What is not a real option: Considering boundaries for the application of real options to business strategy. Academy of Management Review, 29, 7485. 
Adner, R., \& Levinthal, D. A. (2004b). Real options and real trade-offs. Academy of Management Review, 29, 120-126.

Amram, M., \& Kulatilaka, N. (1999). Real options: managing strategic investment in an uncertain world. Boston, MA: Harvard Business School Press.

Anderson, V. (2007). Contingent and Marginalised? Academic development and part-time teachers. International Journal for Academic Development, 12(2), 111-121.

Austin, A. \& Rice, E. (1998). Making tenure viable: listening to early career faculty. American Behavioral Scientist, 41(5), 736-754.

Berk, A. \& Kase, R. (2010). Establishing the value of flexibility created by training: applying real options methodology to a single HR practice. Organization Science. 21, 765-780.

Bhattacharya, M., \& Wright, P. M. (2005). Managing human assets in an uncertain world: applying real options theory to HRM. International Journal of Human Resource Management, 16, 929-948.

Bonnal, L. \& Giret, J.F. (2010), Determinants of access to academic careers in France, Economics of Innovation and New Technology, 19(5), 437-458.

Bowman, E. H., \& Hurry, D. (1993). Strategy through the options lens: An integrated view of resource investment and the incremental-choice process. Academy of Management Review, $18,760-782$.

Brealey, R. A. \& Myers, S.C. (1996). Principles of corporate finance. McGraw-Hill: New York (fifth edition).

Brivot, M., Lam, H. \& Gendron, Y. (2014). Digitalization and promotion: An empirical study in a large law firm. British Journal of Management, 25, 805-818. 
Brown, T., Goodman J., \& Yasukawa, K. (2010). Academic casualization in Australia: class divisions in the university. Journal of Industrial Relations, 52, 169-182.

Bryson, C. (2004), What about the workers? The expansion of higher education and the transformation of academic work, Industrial Relations Journal, 35(1):38-57.

Chakrabortty, A., \& Weale, S. (2016). Universities accused of 'importing Sports Direct model' for lecturers' pay. The Guardian, 16 November 2016. Available at: https://www.theguardian.com/uk-news/2016/nov/16/universities-accused-of-importingsports-direct-model-for-lecturers-pay, accessed 4 January 2017.

Chevalier-Roignant, B., \& Trigeorgis, L. (2011). Competitive strategy: options and games. Cambridge MA: MIT Press.

Chou, Y-C. (2011). Establishment of a temporary workforce transaction mechanism using a real option approach. African Journal of Business Management, 5, 11316-11322.

Clark, B. R. (1997). The modern integration of research activities with teaching and learning. Journal of Higher Education, 68, 241-255.

Coates, H., Dobson, I. R., Goedegebuure, L. \& Meek, L. (2009). Australia's casual approach to its academic teaching workforce. People and Place, 17(4), 47-54.

Connelly, C. E., \& Gallagher, D. G. (2004). Emerging trends in contingent work research. Journal of Management, 30, 959-983.

Copeland, T. \& Tufano, P. (2004). A real-world way to manage real options. Harvard Business Review, 82(3), 90-99.

Ehrenberg, R. G. \& Zhang, L. (2005). Do tenured and tenure-track faculty matter? Journal of Human Resources, 40(3), 647-659. 
Elton, E. J. \& Gruber, M. J. (1995). Modern portfolio theory and investment analysis. Wiley: New York (fifth edition).

Feldman, D.C. \& Turnley, W.H. (2004). Contingent employment in academic careers: relative deprivation among adjunct faculty. Journal of Vocational Behavior, 64(2), 284-307.

Foote, D. A, \& Folta, T. B. (2002). Temporary workers as real options. Human Resource Management Review, 12, 579-597.

Frederickson, C. (2015). There is no excuse of how universities treat adjuncts. The Atlantic, September $15^{\text {th }}$.

Gete, P. \& Porchia, P. (2011). A real options analysis of dual labour markets and the single labour contract. MPRA Paper no. 34055, available online at http://mpra.ub.unimuenchen.de/34055, accessed 2nd July 2013.

Grabher, G. (2004). Temporary architectures of learning: knowledge governance in project ecologies. Organization Studies, 25(9), 1491-1514.

Güelle, M., \& Petrongolo, B. (2007). How binding are legal limits? Transitions from temporary to permanent work in Spain. Labour Economics, 14, 153-183.

Jacobs, B. (2007). Real options and human capital investment. Labour Economics, 14, 913925.

Janney J. J., \& Dess, G. G. (2004). Can real-options analysis improve decision making? Promises and pitfalls. Academy of Management Executive, 18(4), 60-75.

Kalleberg, A. L. (2000). Nonstandard employment relations: part-time, temporary and contract work. Annual Review of Sociology, 26, 341-365.

Kaplan, K. (2010). Academia: the changing face of tenure. Nature, 468, 123-125. 
Kimber, M. (2003), The tenured 'core' and the tenuous 'periphery': The casualisation of academic work in Australian universities, Journal of Higher Education Policy and Management, 25(1), 41-50.

Kogut, B., \& Kulatilaka, N. (2004). Real options pricing and organizations: the contingent risks of extended theoretical domains. Academy of Management Review, 29, 102-110.

Kolb, R. W. (1997). Futures, options and swaps. Blackwell: Malden, MA. (2 ${ }^{\text {nd }}$ edition).

Lotti, F. \& Viviano, E. (2012). Temporary workers, uncertainty and productivity. Available at Society of Labor Economists website http://www.sole-jole.org/13112.pdf, accessed $2^{\text {nd }}$ July 2013.

Luehrman, T. A. (1998). Investment opportunities as real options: getting started on the numbers. Harvard Business Review, 76(4), 51-67.

Maklan, S., Knox, S., \& Ryals, L. (2005). Using real options to help build the business case for CRM investment. Long Range Planning, 38(4): 393-410.

Malos, S. B., \& Campion, M. A. (1995). An options-based model of career mobility in professional services firms. Academy of Management Review, 20, 611-644.

Malos, S. B., \& Campion, M. A. (2000). Human resource strategy and career mobility in professional services firms: a test of an options-based model. Academy of Management Journal, 43, 749-760.

Mangum, G., Mayall, D., \& Nelson, K. (1985). The temporary help industry: a response to the dual internal labour market. Industrial and Labor Relations Review, 38, 599-611.

Massy, W. F. \& Zemsky, R. (1994). Faculty discretionary time: departments and the "academic ratchet", Journal of Higher Education, 65, 1-22. 
McCarter, M. W., Mahoney, J. T., \& Northcraft, G. B. (2011). Testing the waters: using collective real options to manage the social dilemma of strategic alliances. Academy of Management Review, 36, 621-640.

McGrath, R. G., Ferrier W. J., \& Mendelow, A. L. (2004). Real options as engines of choice and heterogeneity. Academy of Management Review, 29, 86-101

Merton, R. (1998). Applications of option-pricing theory: Twenty-five years later. American Economic Review, 88(3), 323-349.

Miller, K. D. \& Walker, H. G. (2003). Scenarios, real options and integrated risk management. Long Range Planning, 36, 93-107.

Mittendorf, B. (2004). Information revelation, incentives, and the value of a real option. Management Science, 50, 1638-1645.

Petersen, B., Welch, D. E. \& Welch, L. S. (2000). Creating meaningful switching options in international operations. Long Range Planning, 33, 688-705.

Pindyck, R. S. (1991). Irreversibility, uncertainty and investment. Journal of Economic Literature 29, 1110-1148.

Pinker, E. J. \& Larson, R. C. (2003). Optimizing the use of contingent labour when demand is uncertain. European Journal of Operational Research, 144, 39-55.

Rice, R. E. \& Sorcinelli, M. D. (2005). Can the tenure process be improved? in R.Chait, R. Chait and R. Baldwin (Eds.) The Questions of tenure, Harvard University Press.

Robin, S. \& Cahuzac, E. (2003). Knocking on academia's doors: an inquiry into the early careers of doctors in life sciences. Review of Labour Economics and Industrial Relations, 17, 1-23. 
Rousseau, D. M. (1989). Psychological and implied contracts in organization, Employee Responsibilities and Rights Journal, 2, 121 - 139.

Ryan, S., Burgess, J., Connell, J. \& Groen, E. (2013). Casual academic staff in an Australian university: marginalised and excluded. Tertiary Education and Management, 19(2), 161-175.

Sanchez, R. (2003). Integrating transaction costs theory and real options theory. Managerial and Decision Economics, 24, 267-282.

Sanyal, S. \& Sett, P. K. (2011). Applying real options theory to HRM: an empirical study of IT software firms in India. International Journal of Human Resource Management, 22, 72102.

Smit, H. T. J. \& Moraitis, T. (2010). Serial acquisition options. Long Range Planning, 43, 85103.

Smit, H. T. J. \& Trigeorgis, L. (2007). Strategic options and games in analysing dynamic technology investments. Long Range Planning, 40, 84-114.

Sydow, J., Lindkvist, L. \& DeFillippi, R. (2004). Project-based organizations, embeddedness and repositories of knowledge: Editorial. Organization Studies, 25(9), 1475-1489.

Trigeorgis, L. (1996). Real options: managerial flexibility and strategy in resource allocation. MIT Press: Cambridge, MA.

Trigeorgis, L. \& Baldi, F. (2012). A real options theory of human resource management. Annual International Conference of the Real Options Group, $28^{\text {th }}-30^{\text {th }}$ June. Available at http://realoptions.org/openconf2012/data/papers/71.pdf , accessed 21 January 2014.

Trower, C. (2005). What is current policy? in R.Chait, R. Chait and R. Baldwin (Eds.) The Questions of tenure, Harvard University Press. 
van Emmerick, H., \& Sanders, K. (2004). Social embeddedness and job performance of tenured and non-tenured professionals. Human Resource Management Journal, 14(1), 40-54.

Zardkoohi, A. (2004). Do real options lead to escalation of commitment? Academy of Management Review, 29(1), 111-119. 


\section{FIGURE 1}

Protective put: a combination created by purchasing a stock and purchasing a put

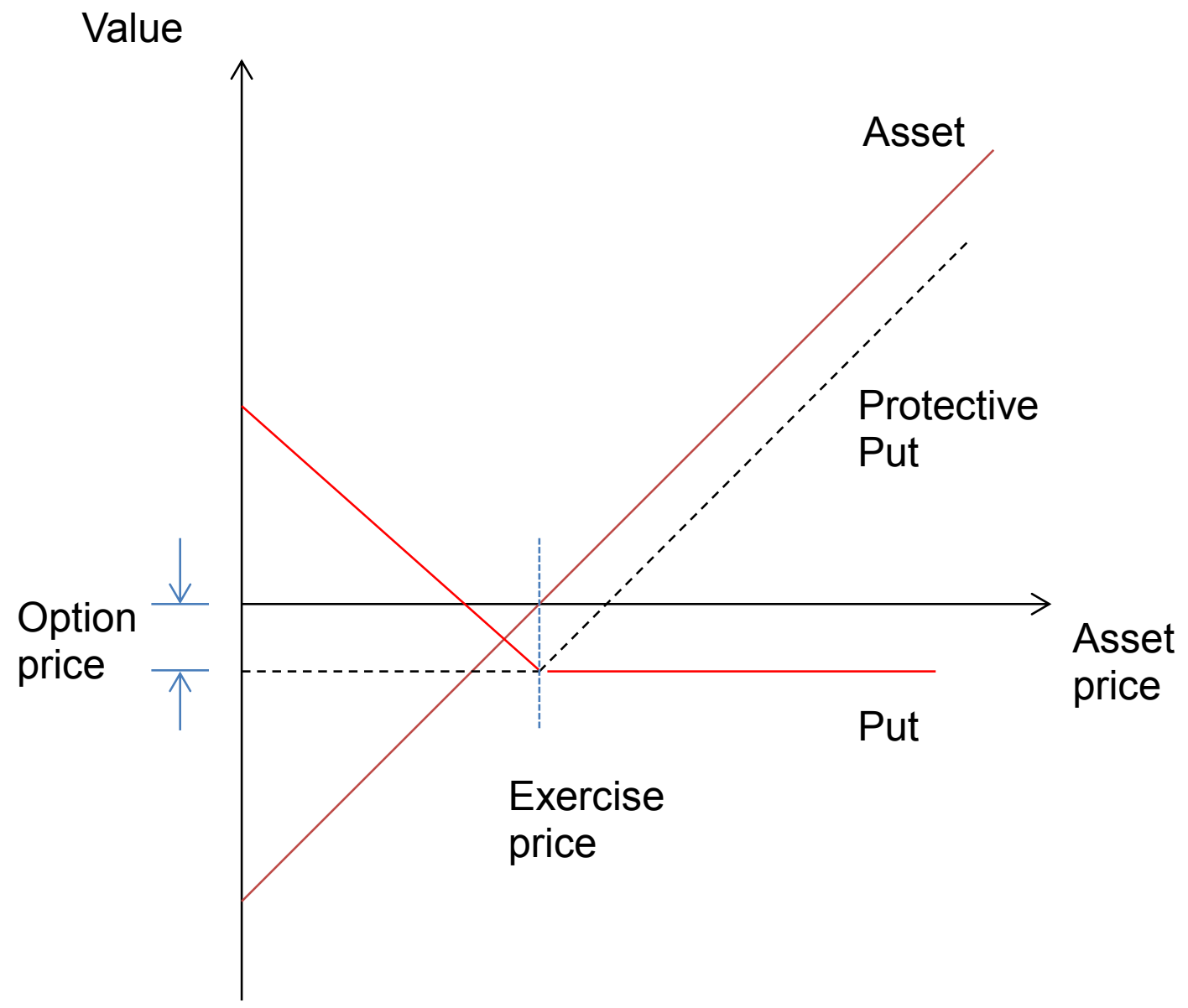




\section{FIGURE 2}

Temporary employment contract modelled as protective put

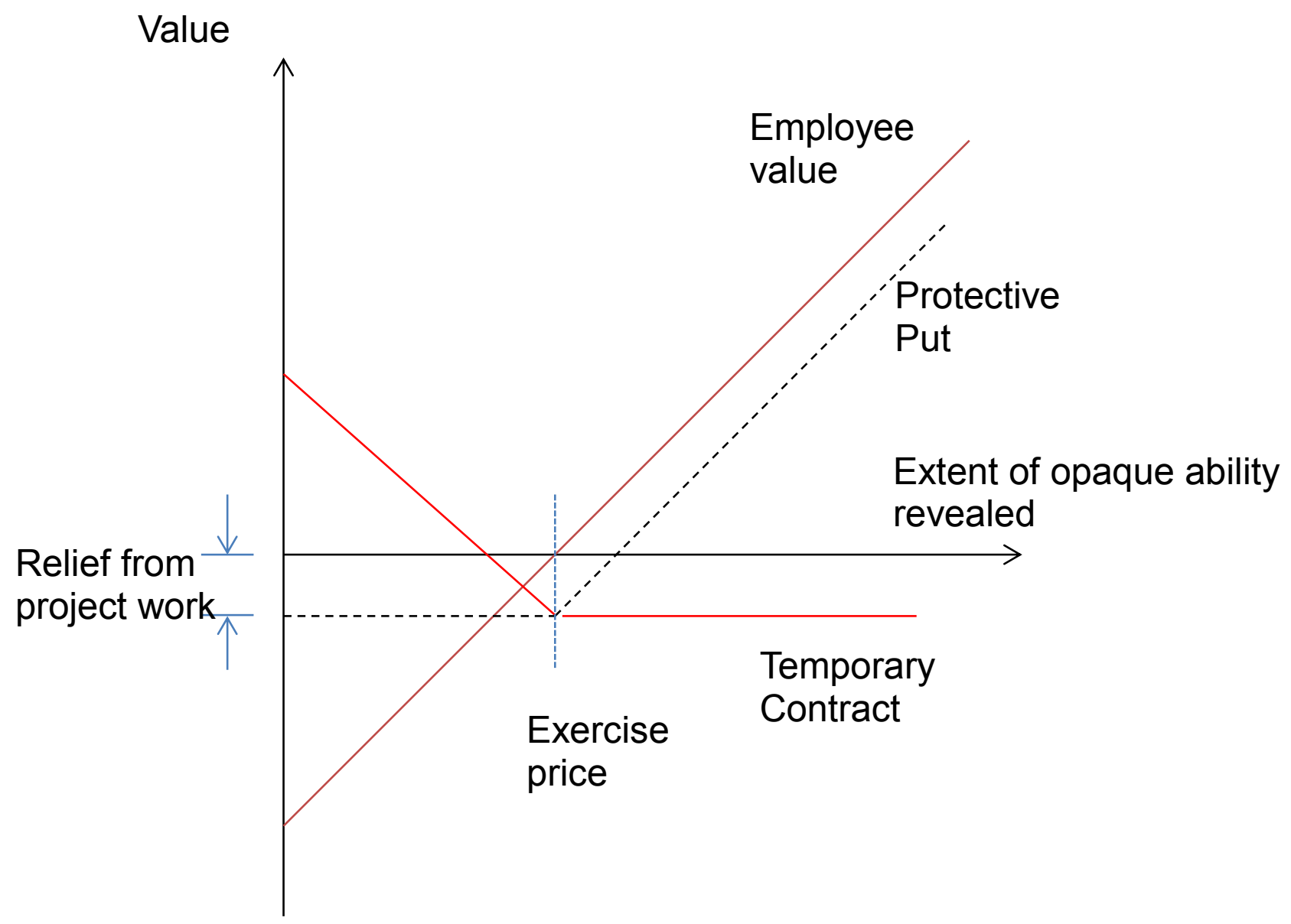


FIGURE 3

Temporary employment contract in academia

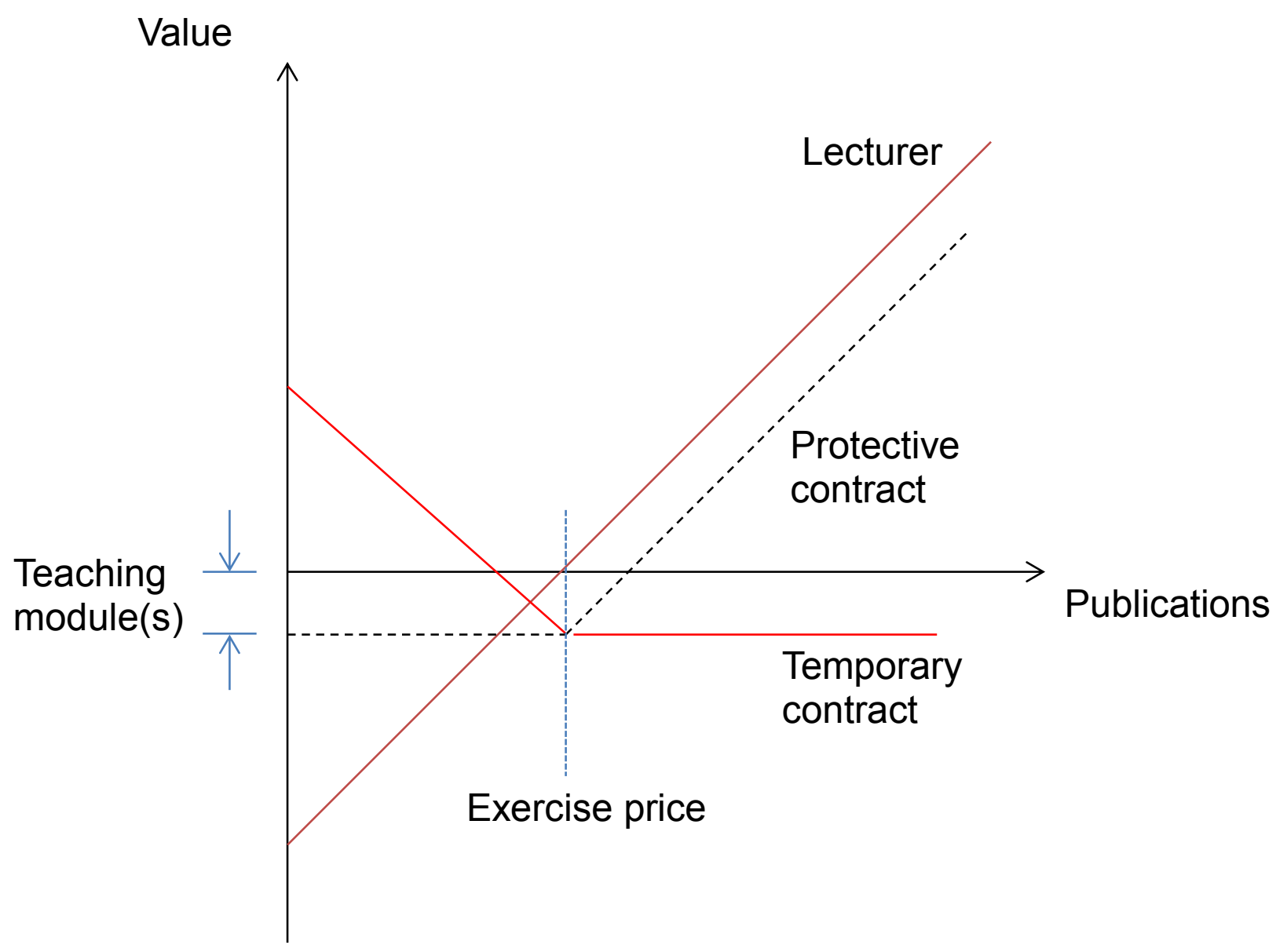




\section{FIGURE 4}

Protective contract for teaching intensive institution

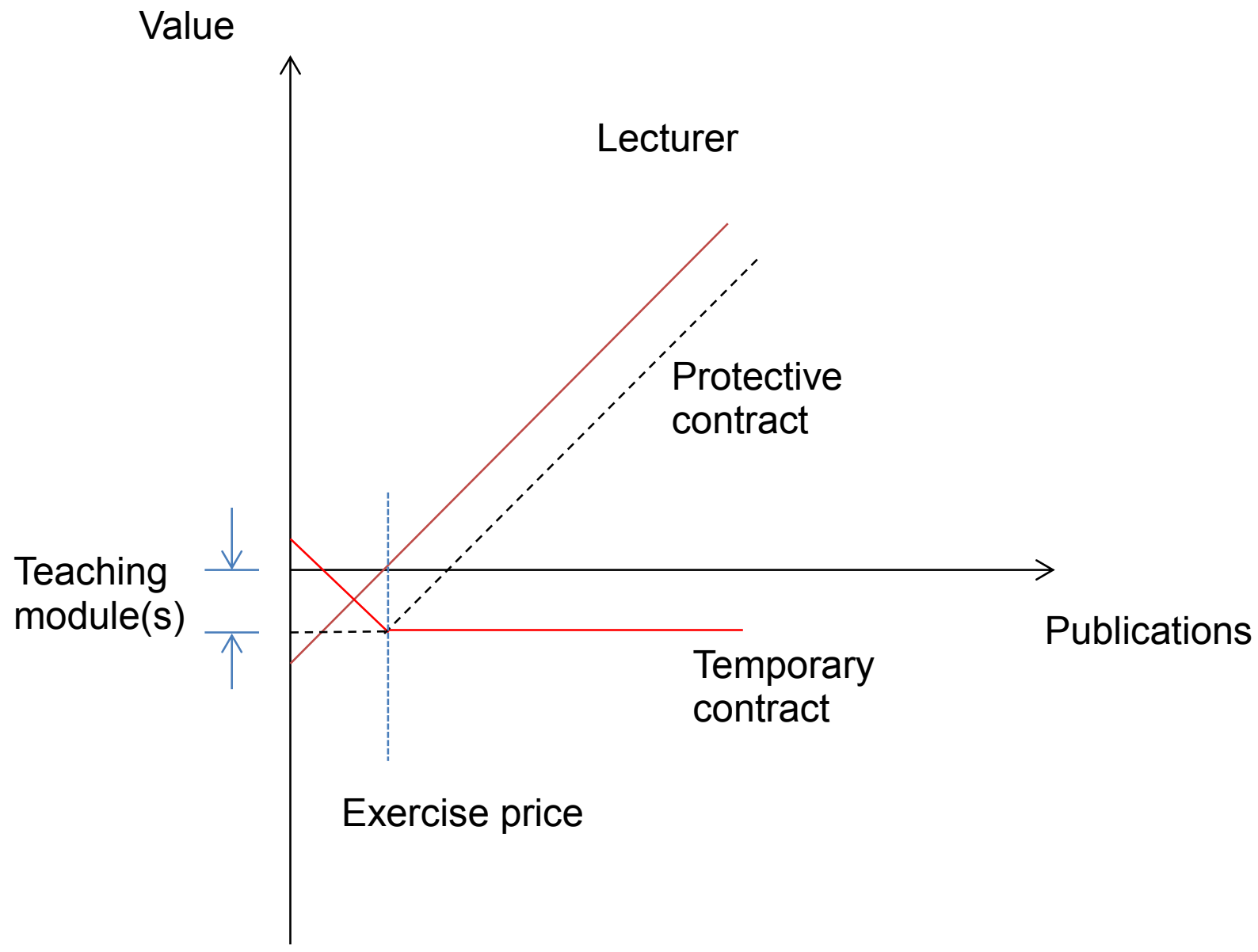




\section{FIGURE 5}

Post-doctoral researcher situation

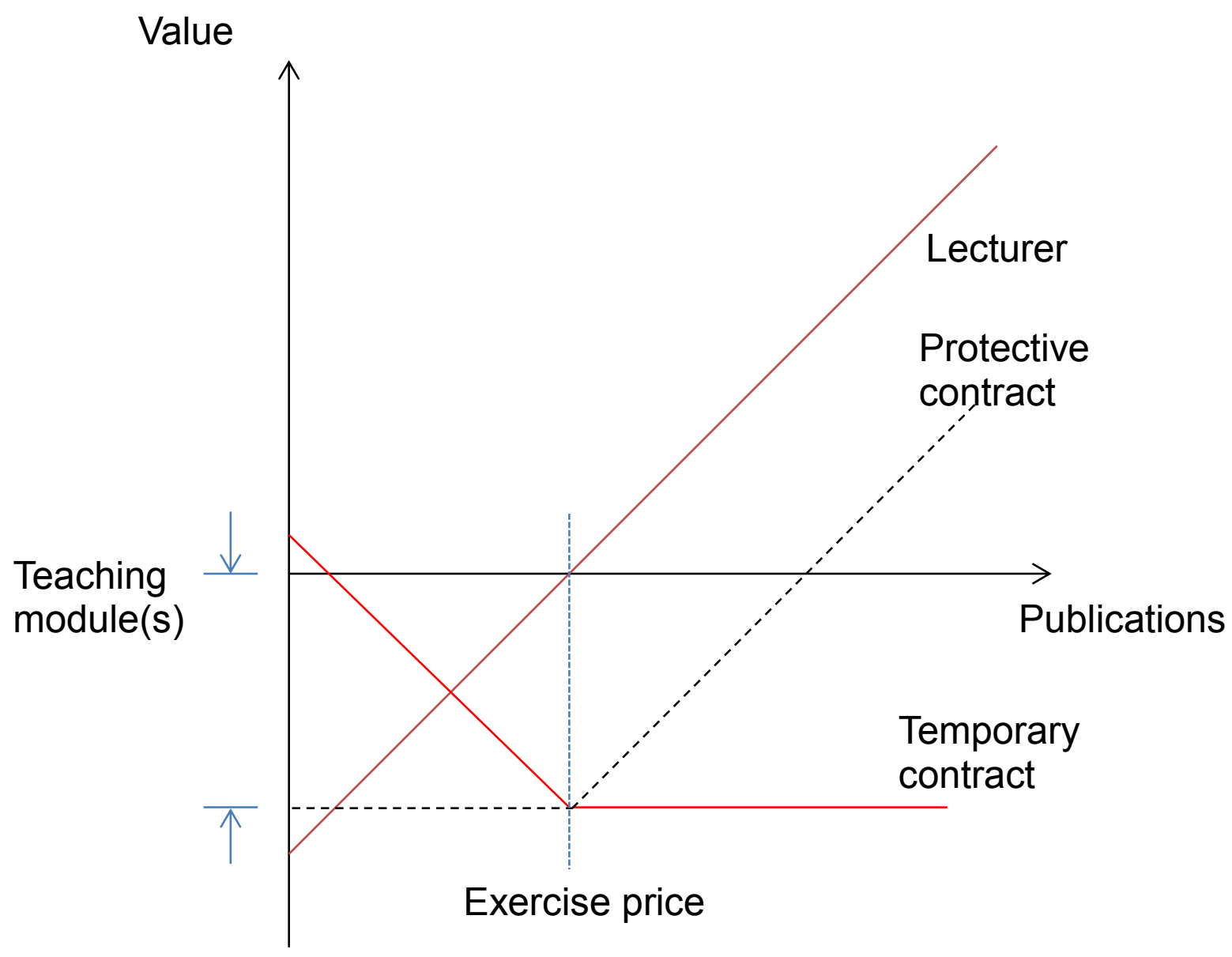




\section{FIGURE 6}

Situation where no teaching relief given

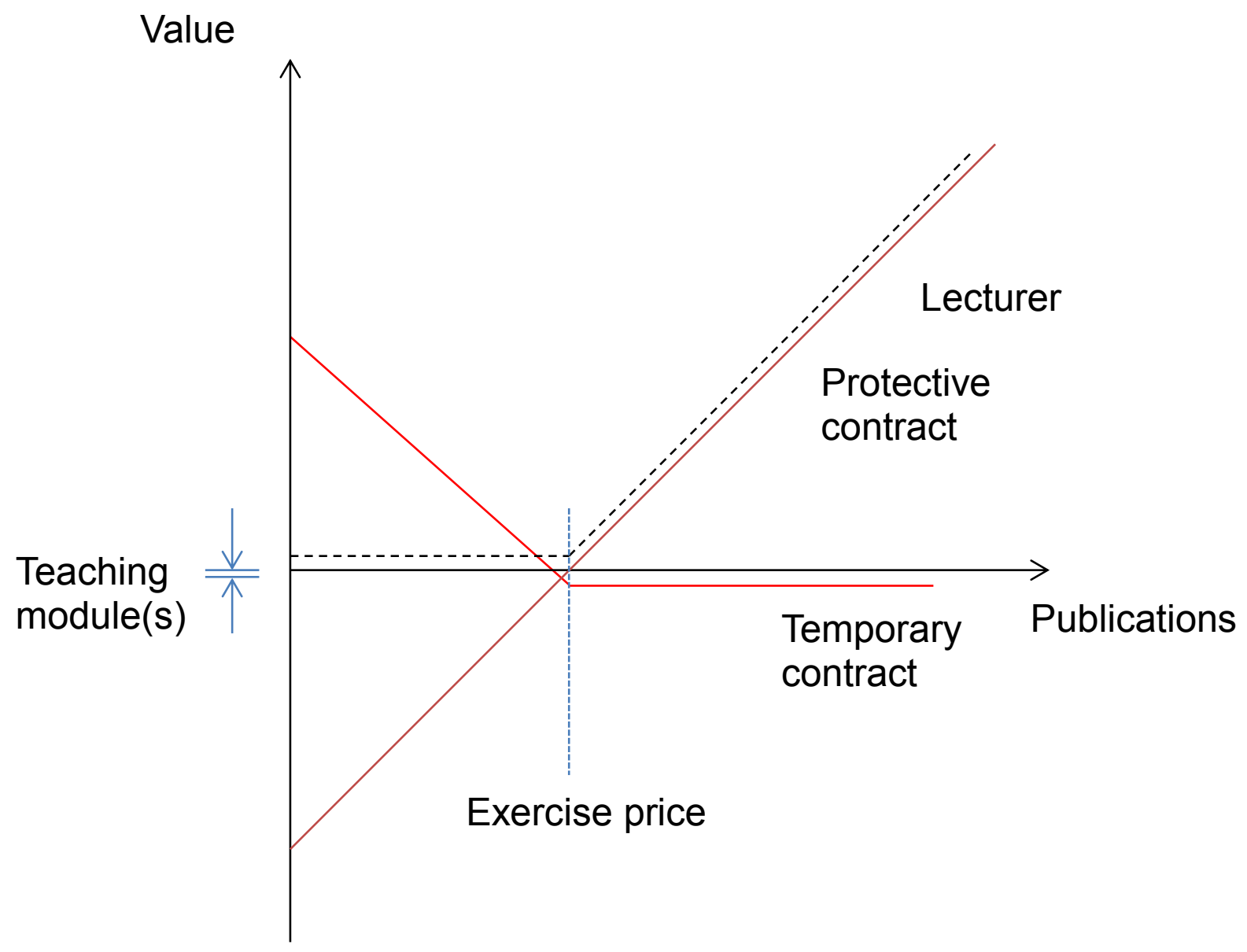

